\title{
GREEN OPEN SPACE IN LARGE SCALE HOUSING ESTATES: A PLACE FOR CHALLENGE
}

\author{
Sandra Treija1, Uğis Bratuškins ${ }^{2}$, Edgars Bondars ${ }^{3}$ \\ Faculty of Architecture and Urban Planning, Riga Technical University, Kalk, street 1, LV-1658 Riga, Latvia

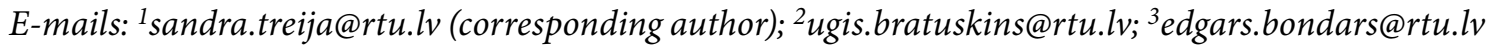

Submitted 08 October 2012; accepted 26 November 2012

\begin{abstract}
The renewal of urban areas by developing green open spaces increases the overall quality of life and helps to reduce social exclusion. Urban green open space can help to constitute a framework where urban society and culture can develop, and to increase identity and a sense of community. It can be used to provide a ground for education and raise an awareness of the way ecosystems function and how urban functions can be integrated into the natural system. Despite the known socio-economic benefits resulting from it, considerations regarding sustainable land use planning often occupy a secondary role when designing city quarters. There exist many pressures - essentially market-related and driven by short-term thinking - for unsustainable development.

Housing ownership reform, carrying out denationalization and privatization, along with a core capital for many inhabitants has also created a range of problems - one of them: as a result of denationalisation of land properties, when the land in large-scale residential districts was returned to the previous owners and then provided as the minimum required land to the privatised buildings, the original spatial composition of districts was completely destroyed, creating a legal basis for new construction in large-scale residential districts.
\end{abstract}

Keywords: public open space, large scale housing, sustainability.

\section{Introduction}

In many European cities mass housing or large-scale residential districts are perceived as degraded territories inhabited mainly by social groups with low-income. Therefore these districts are facing a range of problems, like poverty, high risk of criminality, etc. For the mentioned reasons this housing stock usually is absolutely excluded from the real estate market (Krantz 1999). The poor image of districts prevents people from investing money in development there, and thus the districts and community become even more squalid. To avoid ultimate degradation of the extensive territories the responsible authorities have to invest resources in renovation of buildings and revitalization of the whole area. Since large-scale residential area is the dominant type of living environment in many European cities, wide spectrum of problems involves spatial, aesthetic, technical, economic, and social aspects (Turkington et al. 2004).

Large-scale residential areas with 5-12 storey high apartment blocks constituting about $40 \%$ of the entire housing in Riga were erected in the second half of the $20^{\text {th }}$ century. These urban mega-structures embody se- veral thousand inhabitants each and cover vast areas of the city. Industrialization and mass-production of pre-fabricated housing, strict regulation of the design standards and the rapid increase of construction tempos accounted rapid expansion of large-scale housing estates. Application of the principles of International Modernism and adjustment of them to the local material and technical as well as economic resources was mostly introduced in a repressive way with directives from the centralized supervisory structures for planning and architecture of the USSR. Not all planned quantitative targets were attained, however, about 200,000 apartments in pre-fabricated apartment buildings overall during the period 1958-1990 were built in Riga according to the construction plans. Green open spaces became an important element of residential districts and covered $40-45 \%$ of the territory. They were essential to create favourable microclimate and good sanitary conditions, to establish developed recreational environment for needs of various groups of people and to create expressive and diverse urban landscape in general. 
Research question: Do public open spaces originally planned as an important component of the large-scale housing estates containing spatial, social and environmental functions, now, in 50 years, still remain of the same importance and quality of the living space within the up-to-date standards of environment quality.

A readily accessible public open space is a centre of public activities which may affect the everyday life of people and development of the entire neighbourhood (Rapoport 1985). The public open space is beyond the control of individuals, it is an element linking the private living spaces of inhabitants and it is used for different functional and symbolic purposes (Madanipour 2003). Public open space in the residential environment is the main platform for socialisation as well as an essential component of a dwelling, "an extension" of the personal living space into outer world (Belanger 2007). Gradually people are trying to seize control over it - whether through legal actions or active utilisation or a controlled access for "strangers", attempting to transform public open spaces into public/private spaces (Kearns, Parkinson 2001). Green areas have a positive effect on ecological aspects such as climate, air quality, etc. and physical aspects such as density and balance of openness of urban environment (Hur et al. 2010). Among the social effects of green areas are contributions to social integration through provision of shared experiences and contributions to psychological and physiological health through provision of recreational functions and environmental effects (Dunnet et al. 2002). Since the surroundings largely determine the processes of human life there is a close relationship between the character of the built-up area and human lifestyle.

\section{Context}

The huge large-scale housing estates are a phenomenon of the Soviet era, the establishment which was determined by political, social and economic factors. The construction boom of multi-apartment buildings in Latvia in general and in Riga in particular began in the late 1950s and continued until the early 1990s. This housing stock mostly consists of prefabricated slab apartment blocks. Thirteen districts around Riga historical centre acquired an urban structure that was new by content and form. Every resident within the boundaries of the housing estate was provided with all necessary public services (Krastiňš et al. 1998). According to Gunārs Melbergs, architect, who had designed layout of several large-scale housing estates in Riga: "the layout scheme of the housing estates, which originated in England, derived from the conditions of pretty extensive construction with the height did not exceed four floors and where all everyday processes actually took place in one horizontal level. The underlying principle of this system allowed children to reach educational establishments; schools and playgrounds without parents' assistance and without a need to use transport and cross the streets, besides all their movements could be observed through the apartment's window." The architect also stated that the organization of the built-up area was substantially affected by the requirement to ensure optimal microclimate and sanitary conditions, as well as to arrange public open spaces right next to the dwellings for recreational needs (Melbergs 1979). In the new districts, the traditional pattern of perimeter blocks with corridor-like streets was replaced with free-standing buildings amid the greenery.

Although based on a number of ambitious ideas, soon after starting implementation, the concept of large-scale housing estates was much criticised in Europe. Also G. Melbergs expressed doubts about sustainability of the implemented housing policy: "the scale of residential construction in our country has reached such a level (9 flats per 1000 inhabitants a year) that it prompts a need for serious reassessment of the quality standards applied in this sector" (Melbergs 1979). Green areas in those districts covered $40-45 \%$ of the territory; therefore it was important to determine intensity of usage of them for everyday leisure activities, and whether inhabitants were satisfied with quality of greenery and landscape elements. The survey conducted in 1967 and 1968 under the guidance of Modrite Lūse, architect, indicated that inhabitants of the new housing estates in the Latvian SSR did not use the green areas of inner courtyards much. On average $87.85 \%$ of respondents expressed desire to spend leisure time in the green areas of the housing estates, while only $37 \%$ of respondents actually did it. The main reason was dissatisfaction with the arrangement of these areas, which did not correspond to peoples' notion of well-planned greenery, and which were not appealing either aesthetically or functionally. As a result, large urban areas, where immense resources were invested, were not fully used and the invested funds did not pay off. The decisive factor in increasing usage intensity of residential districts appeared to be the type and appearance of greenery. Usage intensity grew faster in the areas where greenery included mature trees with large crowns. Most of inhabitants wanted to participate in the improvement of greenery in the district they lived in. To involve as many people as possible and to use the dedicated time and energy efficiently, M. Lūse suggested various forms for organisation of community work (figs. 1-4). 


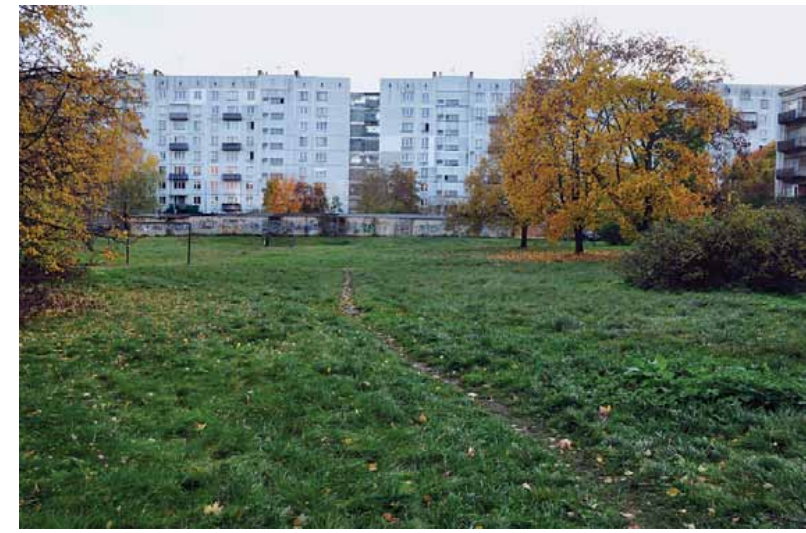

Fig. 1. Existing characteristic green open space in Large-scale housing area

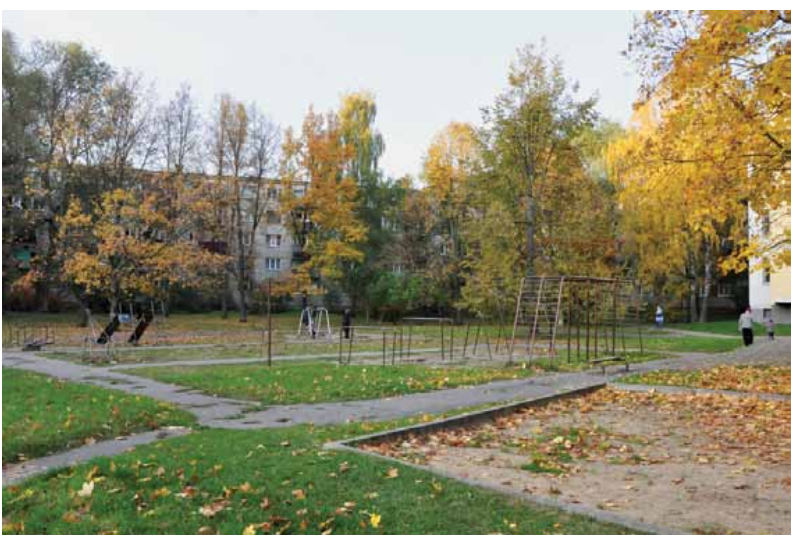

Fig. 3. Average condition of equipment quality in green open areas

As a result of denationalisation process (1992-2005) the propriety of land was re-established to the former owners or their legal heirs. Since the large-scale housing estates were planned in the conditions of socialism where all land belonged to the state the layout of buildings was not consistent with the former borders of the land. With denationalisation the united spatial composition of the districts was disarranged and legal basis for possible new construction in the non-built areas (i.e., public open spaces) such as large-scale housing estates was created (Treija 2009). The economic growth between 2001 and 2007 increased the demand for housing in Riga. It is estimated that over five years about 50 residential buildings with more than 1000 apartments were built in the public open spaces of large-scale housing estates. It reduced areas of habitual free spaces and resulted in protests of inhabitants of surrounding buildings. Respecting this, Riga City Council in 2006 imposed a moratorium on new construction in inner courtyards. The moratorium referred to approximately 1700 plots in courtyards, what is

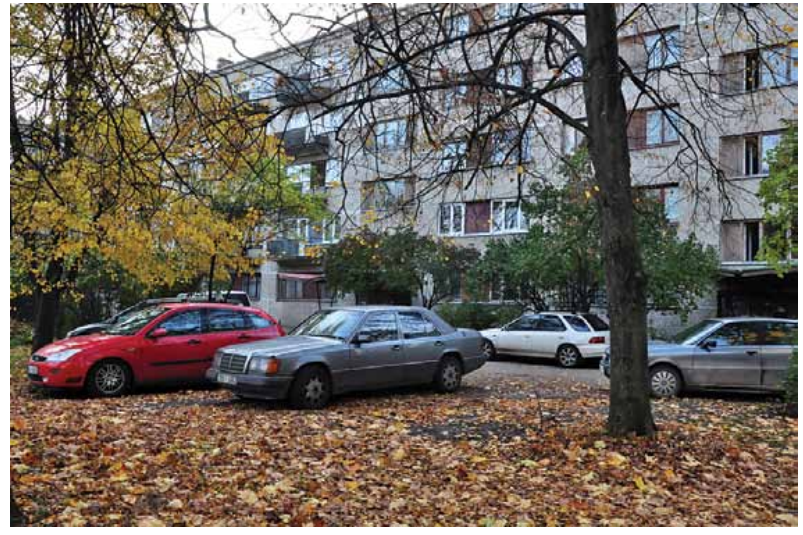

Fig. 2. Traditional usage of green open areas

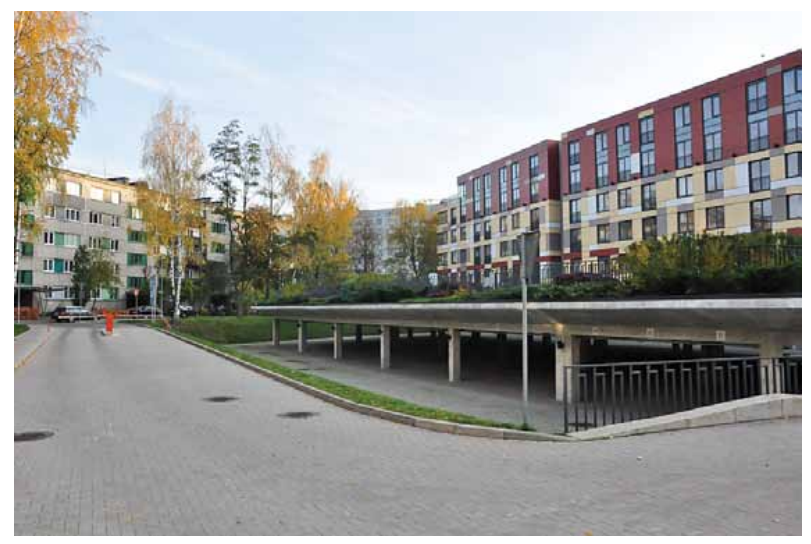

Fig. 4. New infill in the existing urban structure impact quality of usage of open spaces

almost five per cent of the total area of the whole city. In December 2009 due to changes in Riga Building Regulations, a moratorium on building courtyard was cancelled (Treija et al. 2010).

\section{Selection of a place - case of Purvciems}

In the initial phase of large-scale residential construction a spacious courtyard surrounded by standard multi-storey apartment blocks was seen as the most important element of a public open space (Strautmanis et al. 1987). Purvciems is one of the largest residential districts. It was built between 1965 and 1975 in Riga, and is a typical example of that time large-scale housing estates (architects G. Melbergs, R. Paikune, M. Medinskis and others). The spatial plan of the estate bristles with pararegular (derived from regular, complex - authors' remark) and polygonal shape structures. They are based on a regular $120^{\circ}$ module system where a five-storey residential building forms each side of a hexagon. The main streets and public activity centres are emphasized with separate rows of nine-storey 

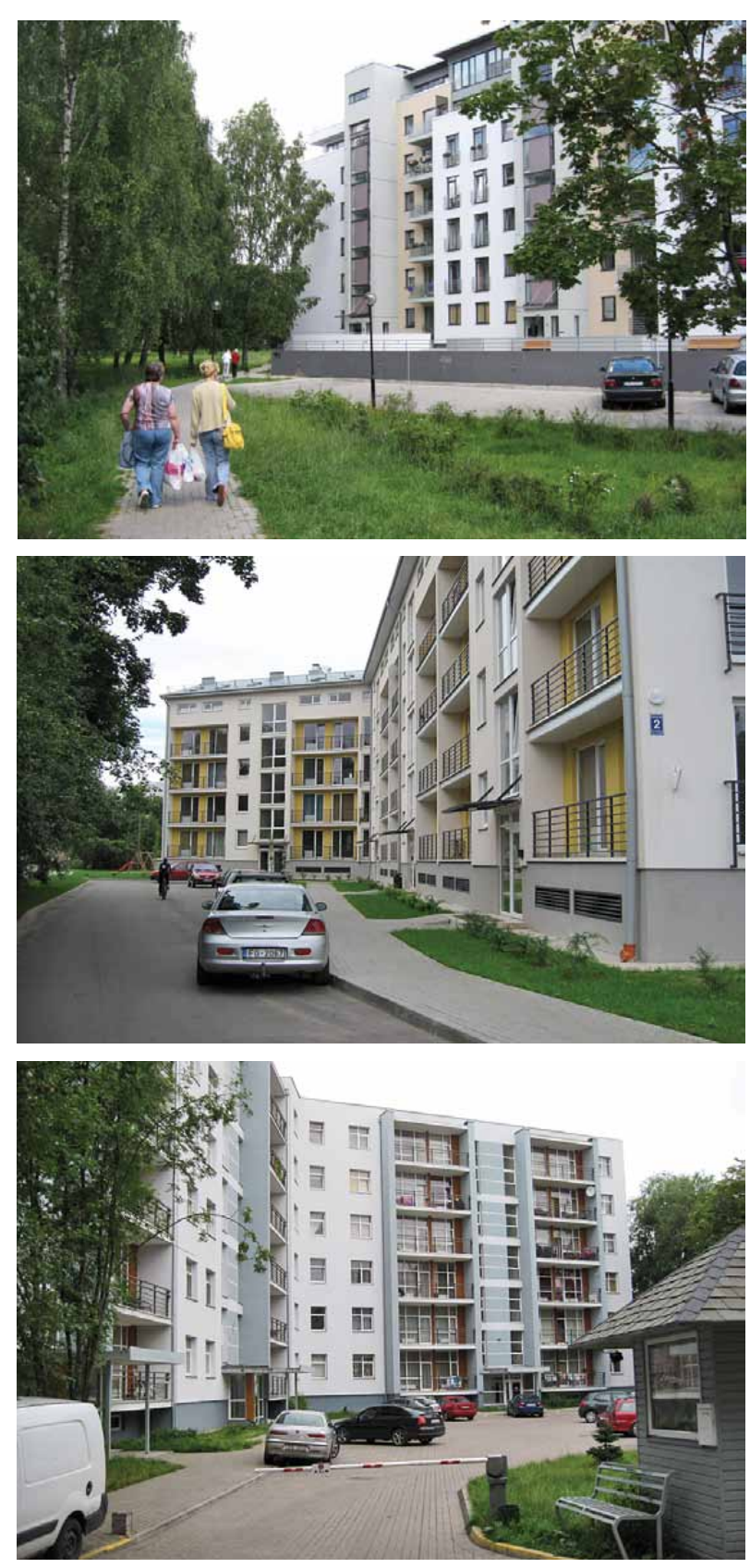

Figs. 5-7. New residential buildings built in former green open space in Purvciems

buildings. The spacious areas of inner courtyards are designed for recreational needs. Part of the built-up area of the district is intensively restructured by construction of new high-rise apartment buildings in the inner courtyards (figs. 5-7), while no similar activities are found in other parts of the district.

Two different courtyards were selected as case studies of the research: one of the courtyards had retained its historic built-up structure, while the spatial structure of the other one was supplemented with a new five-storey residential building (fig. 8). The basic built-up structure consists of 9-storey section-buildings (section is a separate full-height block designed in plan around the vertical communications - stairs, elevators, and may be placed side-by-side to another section or sections thus forming the entire building) as well as of 5-storey four and six section buildings arranged along one side of the street. The five-storey buildings are positioned in the plan at a $120^{\circ}$ angle, form hexagonal inner courtyards. New infill buildings have appeared in almost all inner courtyards in the quarter bordering on Ünijas, Stirnu, Dzelzavas and Vaidavas Streets. The main built-up area consists of 17 foursection five-storey buildings, 3 six-section five-storey buildings and sections of 9 -storey buildings (altogether 20 sections) aligning the main arterial road - Dzelzavas Street. A new kindergarten is located in one of the inner courtyards, and several multi-storey apartment buildings are constructed in five courtyards. Three public buildings are built in the courtyard opening towards Vaidavas Street: a building material shop, a grocery store and a pharmacy, a café and a hairdressing salon. In the surrounding area several public service objects are located - schools, sports centres, a supermarket, a health-care centre, etc. Most of these objects are concentrated directly around the quarter where the intensity of new development is higher. Public transport (buses, trolley buses and mini buses) runs along Vaidavas, Dzelzavas and Stirnu Streets. There are 13 public transport stops along the perimeter of the quarter. Daily pedestrian transit flow in inner courtyards is very intense, as people cross them walking to and from service objects. The courtyards have to meet not only transit pedestrian but also other utilitarian functions. Thus, the residents of standard buildings are to park their cars along the inner access roads in the courtyards and on the green belts along the roadsides, as well as directly in front of the entrances of the buildings. In one of the inner courtyards a separate parking lot is established in the place of a former sports ground, near the new residential buildings. On the contrary, the residents of the new courtyard infill usually can use private car parks that are placed under the new buildings.

\section{Method 1: survey}

In the autumn of 2008, as part of the project "Usage Intensity of Inner Courtyards in Purvciems - a Largescale Housing Estate in Riga" in order to find out public opinion about the importance and role of public open spaces in the assessment of the quality of life in large-scale housing estates, a public survey was held. 


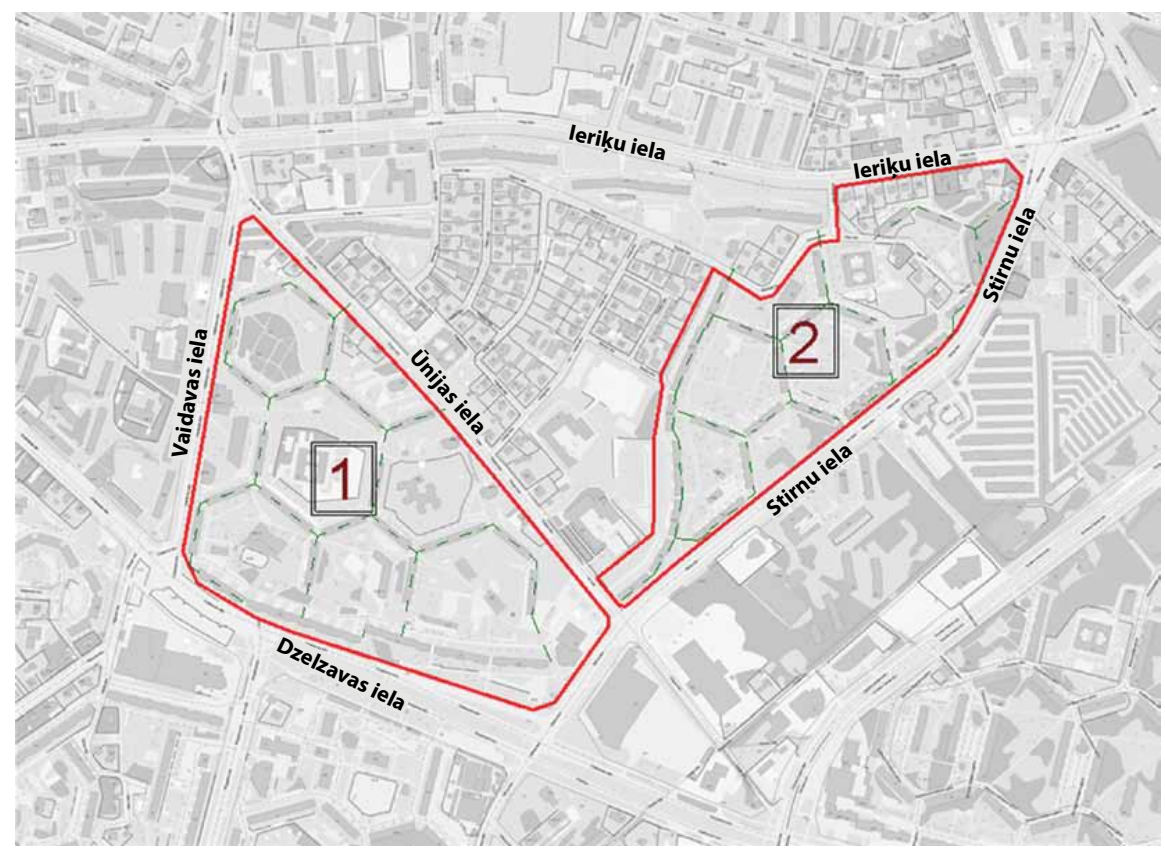

Fig. 8. Sites of the research in northern part of Purvciems

A quantitative direct (face-to-face) method of interviewing was used in the survey, focusing on several objectives:

1. General assessment of spatial quality in largescale housing estates.

2. Determination of level of satisfaction of the residents of large-scale housing estates with different aspects of the living environment.

3. Ascertaining the role of public open spaces in establishing and maintenance of social contacts among inhabitants.

As many as 246 people residing in the northern part of Purvciems were questioned in the territory bordering on Vaidavas, Dzelzavas and Stirnu Streets. A predominant number of respondents - $92 \%$ were residents of multi-storey apartment houses. Among them, 68\% were females, $32 \%$ - males. The majority of respondents were people aged $35-54.28 \%$ of respondents represented households with children. Most of the respondents were living in the area for 10 years and more (47\%). Only $7 \%$ were the new occupants, who live in the current dwelling for less than one year.

\section{Method 2: inventory of activities}

Along with the data of population survey, the inner courtyards of large-scale housing estates were also analysed. In 2009, the study was performed to find out the type and intensity of utilisation of inner courtyards in Purvciems.
Construction of new buildings within the existing built-up area leads to significant changes in architectural and spatial environment. New construction not only leaves a considerable impact on spatial perception of the environment but also introduces social and functional changes in a well-structured residential district where no such construction was previously planned. Emergence of new structures within the courtyards of large-scale housing estates has a direct influence on the utilisation of public open space. In order to determine how intensively and in what manner the inner courtyards of housing estates are used, the inventory of activities the local residents perform in different seasons, on different days of week and at different times of day is the best method to provide the most accurate results.

In two courtyards, landscape improvement elements were enumerated and intensity of courtyard usage was measured. The inventory list of landscape elements included number of benches, their seating capacity, as well as number of playgrounds, parking spaces and cars, number of trees.

The inventory of activities was performed in two periods. The first part of data was collected in summer during the school holidays when many schoolchildren spent their holidays out of the city. The second part of data was collected in autumn when schoolchildren were back from holidays. In each of those periods intensity of courtyard usage was measured both on weekdays and at weekends. As it could be assumed, 
the courtyards turned out to be mostly used by children and young people.

During the process of collecting data, the following types of activities were listed:

1. Pedestrian flow in the territory:

a) transit flow in the territory when residents of other buildings were crossing the courtyard;

b) pedestrian flow across the courtyard when people were going to work, shops, etc.;

c) cycling.

2. Usage intensity of the recreational function of the courtyard:
a) relaxation, sitting on benches;
b) walking;
c) sunbathing;
d) activities in playgrounds;
e) children's activities in other parts of the ter- ritory.

3. Household activity and cleaning of the territory:

a) dog walking;

b) tending the greenery;

c) cleaning the territory;

d) other household activities, disposal of waste, etc.

The inventory was held during several periods from 8.00 a.m. to 9.00 p.m., recording on the site the number of people performing one of the above described activities in each particular period of time.

\section{Survey results}

The results of the study proved that the assessment of spatial quality in the large-scale housing estates is relatively high. According to the survey, overall $72 \%$ of the population like the district. Respondents mentioned nearest shop or other service object, as well as the number and location of educational establishments in the area as the most appealing qualities. $68 \%$ of residents are satisfied with public transport access in the area. Inhabitants in the age group over 70 are most satisfied with their district, and people aged 18-34 are least satisfied. Most of respondents (63\%) do not like the level of safety in the district mainly caused by insufficient lighting in the dark part of the day and a number of gaming clubs located in the vicinity.

What regards the improvement quality of the residential district, most satisfied were inhabitants in the age group over 70 . Generally, $67 \%$ of respondents were not satisfied, mentioning the neglected courtyards and greenery, destroyed landscape elements, lack of benches and playgrounds as the main reasons. 34\% of respondents used the courtyard only as a parking, $26 \%$ admitted that they did not use the courtyard at all. $78 \%$ of inhabitants mentioned that they did not know their neighbours - inhabitants of the adjacent buildings. Inhabitants were also dissatisfied with insufficient parking options near their homes.

\section{Results of inventory - actual intensity of courtyard utilisation}

The vacant courtyard includes nine benches with the total seating capacity of 36 . Its pentagonal shape is formed by one nine-storey building and four sections of five-storey buildings where two of them are facing the courtyard (120 apartments). There are no parking lots at the buildings. Cars are parked at the sides of the access road and, considering its length, there is parking space for about 16 cars. However, as cars are also parked in the green area beside the road and in forecourts in front of entrance doors, there are about $30-40$ cars located at the buildings. There is one playground in the territory, while the green area with 50 trees covers its largest part. There is a site for three household waste containers in the courtyard.

There are no benches in the yard where the new buildings are located. The courtyard area is fenced in by four five-storey buildings and two nine-storey buildings. Six entrances of the nine-storey building are facing the courtyard (162 apartments). The roadsides are also used for parking in this courtyard, and there are about 30 cars. In the central part of the yard, there is an old playground. There are 25 trees in the territory and the lawn covers its largest part. A site for four waste containers is located in the yard. The new building is located within the courtyard, facing eastwards and being retracted $20 \mathrm{~m}$ from the centre of the yard where some new parking spaces are arranged (about 20 cars) with additional parking spaces also arranged underground. The apartments in the new building are grouped around three staircases. Between the new building and the existing ones there is a 20 meter wide and 70 meter long courtyard space, which, although open to the public, is spatially separated from the rest of the courtyard territory and thus, it is almost neglected. The new building has not added any elements of spatial quality or improvement to the existing built-up environment.

In all reviewed periods, regardless of time and season, both yards are most intensively used as transit areas (Figs. 9, 10). Residents of surrounding houses and blocks cross the courtyard area diagonally, either going to work or coming home, going to service objects located along the perimeter of the block, or between different service objects. The movement from and to home of the people who reside in the buildings surrounding the courtyard form the other major activity, so it is also 

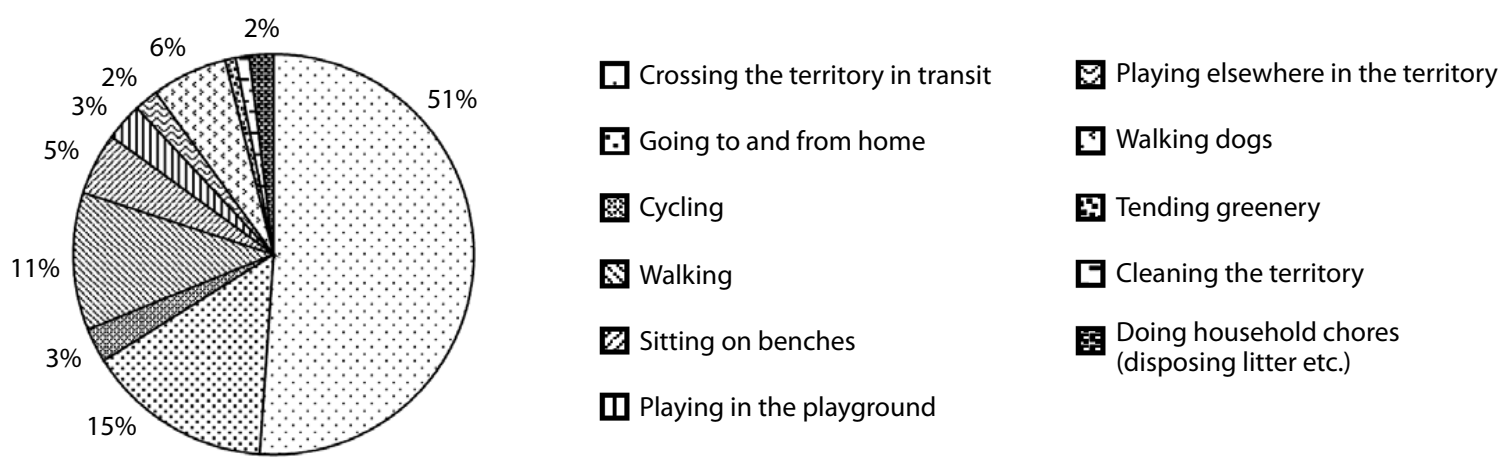

Fig. 9. Type of usage of the vacant inner courtyard
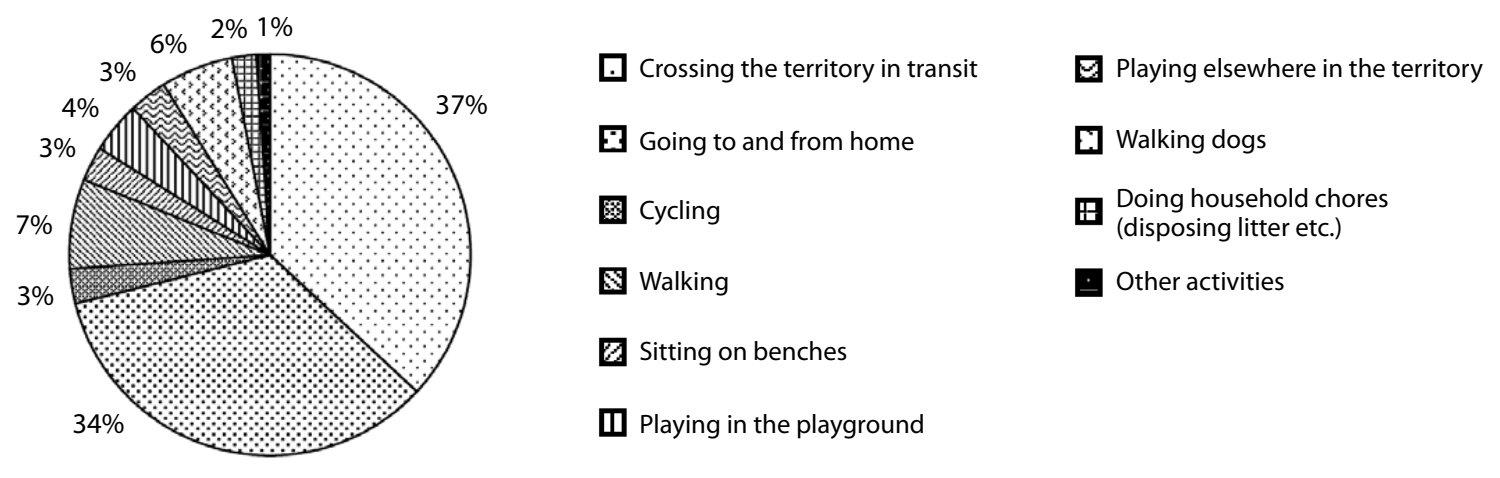

Fig. 10. Type of usage of the built-up inner courtyard

merely crossing the yard without any other purpose of utilisation. Considerably less people use the yard for walking. Only a small proportion of all listed groups of people used the yard for walking, playing or other forms of recreation.

\section{Comparison of survey and inventory data}

Overall, the inventory data regarding the existing situation in the living environment corresponds to the negative evaluation of the improvement level in the courtyard, lack of benches and bad condition of playgrounds produced by population survey. According to previous experience in Latvia, insertion of infill into the built-up structure of a residential district mostly receives negative assessment from the population. However, this process may have a positive effect since the existing environment has considerably deteriorated and new development could improve the quality of courtyards. Practically, new developments often ensure only few most necessary functions, e.g. parking spaces for the residents of the new infill. It is assumed that the inhabitants from the existing buildings will share courtyard with the newcomers from the infill thus the existing playground and other courtyard elements will be used in more intense way introducing no improvements into the existing environment. In this way, transformation of the urban structure of the district does not have positive effect, while the residents of the existing buildings retain their negative attitude towards the new development, as it supposedly considerably reduces the area of the green zone. In this context, it is important to ascertain whether reduction of the usable courtyard area worries residents because they will have fewer opportunities for relaxation or there are emotional considerations at work, since, according to survey results, more than half of the population does not use courtyards for recreational purposes at all.

The survey results show that a considerably smaller proportion of population uses courtyards every day than it was initially suggested. Besides, the survey did not focus on the frequency of use. In addition to the fact that people were worried about the safety issues, the inventory data revealed the disproportionately intensive pedestrian transit flow through the courtyard, past the benches and playgrounds. Likely, in the courtyard where people have to encounter random passers-by more frequently than friends and neighbours, it is difficult to feel safe and emotionally secluded and protected. To some extent, it justifies the tendency when fenced-off private inner yards are established around the new buildings, although this 
tendency in itself is unwelcome, since it aggravates the conflict between the existing built-up area and the new development in no way improving the quality of the existing living space.

\section{Conclusion}

The research leads to a conclusion that the significance of public open spaces of large-scale housing estates of Riga has changed during the first decade of the 21st century. Their initially planned meaning has reduced. Although public open spaces are treated as an important element of the living space, their real usage considerably differs from the intended one. The reasons are associated with social as well as economic aspects. In most cases landscape elements and greeneries planned in the original projects were not arranged and open spaces were not regularly tended and renewed, what led to their gradual degradation. As a result, they have created an image of a neglected, unsafe, unappealing environment, and today often are simply treated as territories with unused potential for new housing. The up-to-date challenge is to enhance the public open spaces of large-scale housing estates by improving the existing quality and determined introduction of new elements.

\section{References}

Belanger, H. 2007. Public Spaces in Gentrifying Neighbourhoods: Conflicting meanings? European Network for Housing Research [online], [cited 12 April 2010]. Available from Internet: http://www.enhr2007rotterdam.nl

Dunnett, N.; Swanwick, C.; Woolley, H. 2002. Improving urban parks, play areas and green spaces, Report for Department for Transport, Local Government and the Regions. London.

Hur, M.; Nasar, J. L.; Chun, B. 2010. Neighborhood satisfaction, physical and perceived naturalness and openness, Journal of Environmental Psychology 30: 52-59. http://dx.doi.org/10.1016/j.jenvp.2009.05.005

Kearns, A.; Parkinson, M. 2001. The significance of neighbourhood, Urban Studies 38(12): 2103-2110. http://dx.doi.org/10.1080/00420980120087063

Krantz, B. 1999. Large Scale Housing Estates in North-West Europe: Problems, Interventions and Experiences. Delft: Delft University Press, 1-13.

Krastiņš, J.; Strautmanis, I.; Dripe, J. 1998. Latvijas Arhitektūra no Senatnes Lìdz Mūsdienām. Rìga: Baltika.

Lūse, M. 1971. Latvijas pilsētu dzīvojamo kvartālu apstādījumu izmantošana, Arhitektūra un Pilsētbūvniecība II. Rīga: Zinātne, 159-176.

Madanipour, A. 2003. Public and Private Spaces of the City. London \& New York: Routledge.

Melbergs, G. 1979. Dažas mājokḷu celtniecības problēmas pilsētekolog̣ijas skatīiumā, Latvijas PSR Pilsētu Arhitektūra. Rìga: Zinātne, 132-139.

Rapoport, A. 1985. Thinking about home environments, in I. Altman, C. M. Werner (Eds.). Home Environments. New York: Plenum Press, 287-309.
Strautmanis, I.; Buka, O.; Krastynsh, Ia.; Asaris, G. 1987. Arkhitektura Sovetskoj Latvij. Moskva: Strojizdat.

Treija, S. 2009. Housing and social cohesion in Latvia, in A. Holt-Jensen, E. Pollock (Eds.). Urban Sustainability and Governance. New York: Nova Science Publishers, 197-207.

Treija, S.; Bratuškins, U.; Suvorovs, E. 2010. The use of public open spaces in large-scale housing estates in Riga, Architecture and Urban Planning. Riga: Riga Technical University, 44-49.

Turkington, R.; van Kempen, R.; Wassenberg, F. 2004. High-rise Housing in Europe. Current Trends and Future Prospects. Delft: Delft University Press.

\section{SANDRA TREIJA}

Doctor of Architecture, Prof., Deputy Dean, Faculty of Architecture and Urban Planning, Riga Technical University, Kalk $u$ street 1, LV-1658 Riga, Latvia.E-mail: sandra.treija@rtu.lv

Architect (1992), MA (1997), Dr Arch. (2006), Riga Technical University (RTU). Research fields: sustainable housing, regeneration of neighbourhoods, sustainable urban development, quality of residential environment. Publications: contributor of the text-book Urban Sustainability and Governance. New Challenges in Nordic Baltic Housing Policies, New York: Nova Science Publishers (2009), author over 30 scientific publications. Member of Editorial Boards of the Scientific Journals Architecture and Urban Planning (Riga Technical University), Landscape Architecture and Art (Latvian University of Agriculture). Membership: LAS (Latvian Union of Architects), IFHP (International Federation for Housing and Planning), coordinator of DOCOMOMO (International Committee for Documentation and Conservation of Buildings, Sites and Neighbourhoods of Modern Movement) Latvian working group.

\section{UG̣IS BRATUŠKINS}

Doctor of Architecture, Prof., Dean, Faculty of Architecture and Urban Planning, Riga Technical University, Kalku street 1, LV-1658 Riga, Latvia.E-mail: ugis.bratuskins@rtu.lv

Architect (1984), MA (1992), Doctor of Architecture (2006), Riga Technical University (RTU). Research fields: up-to-date consequences of development of historical urban structures and city environment, public use and quality of urban space. Publications: more than 40 publications in national and international issues. Membership: Member of National Branch of DOCOMOMO and Foundation of Romualdo Del Bianco (Florence, Italy). Member of Editorial Boards of scientific journals Urbanistika ir Architektūra (Vilnius, Lithuania), Landscape Architecture and Art (Jelgava, Latvia) and Arhitektūra un pilsētplānošana (Riga, Latvia). Member of Editorial Board of magazine Latvijas Arhitektūra ( Riga, Latvia ). Consulting Member of Council for Preservation of Riga Historic Centre.

\section{EDGARS BONDARS}

Doctoral student, Faculty of Architecture and Urban Planning, Riga Technical University, Kalku street 1, LV-1658 Riga, Latvia. E-mail: edgars.bondars@rtu.lv

Architect (2007), MA (2009), Riga Technical University (RTU). Research fields: principles of implementation of the idea of sustainable development in architecture, bioclimatic designing. 